\title{
Long-term effects of prenatal and neonatal exposure to cortisone on the pituitary corticotrophs and folliculostellate cells in rats
}

\author{
Tarek A. El-Ghamrawy, and Laila A. El-Sayed \\ Department of Anatomy and Physiology, \\ Faculty of Medicine, Cairo University
}

\begin{abstract}
Background The objective of this study is to demonstrate the effects of prenatal and neonatal taking of glucocorticoid (GC) on the morphology of the pituitary gland corticotrophs and folliculostellate (FS) cells and the experssion of lipocortin 1 (LC1; annexin I) which is a mediator of many actions of GC. Material and Method Sixty adult male and female albino rats, weighting 200-230 $\mathrm{g}$ were used in this study pregnant and lactating rats were divided into control and treated groups (5rats per group). Treated groups with GC were given it via drinking water $(1 \mathrm{ug} / \mathrm{ml})$ to the rats on d 16-19 of pregnancy or in first week following delivery for lactating rats. Results: The optical density of ACTH antibody andS100 protein antibody were significantly decreased in both prenatal and neonatal groups of dexamethasone administration compared to the control, prenatal dexamethasone treated group produce long-term changes in morphology. Also there was significant reduction in prenatal and neonatal level of annexin-1gene expression when it was compared to the control group. Conclusion: there were significant effects of GC administration in prenatal and neonatal rat groups in the form of morphological and physiological changes
\end{abstract}

\section{INTRODUCTION}

Stress hormones are candidates to mediate changes on the development. Synthetic glucocorticoid (GC) like betamethasone are used in prenatal and early neonatal life to enhance the lung maturity in preterm delivery ${ }^{(\mathbf{1})}$.

Glucocorticoids have potent effects upon tissue development Indeed, it is the accelerated maturation of organs, notably the lung ${ }^{(2)}$, which explains their widespread use in obstetric and neonatal practice in threatened or actual preterm delivery. Glucocorticoid receptors (GR), which are members of the nuclear hormone receptor superfamily of ligandactivated transcription factors, are expressed in most foetal tissues from the early embryonal stages ${ }^{(3,4)}$. Expression of the closely related, higher affinity mineralocorticoid receptor (MR) has a more limited tissue distribution in development and is present only at later gestational stages, at least in rodents ${ }^{(\mathbf{5})}$.

Additionally, GR are highly expressed in the placenta, where they are thought to mediate metabolic and anti-inflammatory effects. Clearly, systems to transduce glucocorticoid effects upon the genome exist from early developmental stages, with complex cell-specific patterns of expression,and presumably sensitivity, to the steroid ligands ${ }^{(\mathbf{6})}$.

FS cells are the nonendocrine, agranular cells in the anterior pituitary. These star-shaped cells 
cluster together to form follicles and extend cytoplasmic processes that connect with processes of endocrine cells. FS cells are characterised by their content of S100 protein, a nonhormonal marker, however, the precise functions of the FS cells in the anterior pituitary gland have not been well characterized. Several functions have been ascribed to FS cells including supportive and trophic effects, roles in ion transport, phagocytic and catabolic activities ${ }^{(7)}$, and many paracrine functions. With their long cytoplasmic processes rich in gap junctions extending between other endocrine cell types, the FS cells are in an ideal position to play a role in intercellular communication mechanisms.

Indeed there is substantial evidence that FS cells modulate the release of pituitary hormone secretion from surrounding endocrine cells through the release of several bioactive molecules (e.g. follistatin, IL-6, nitric oxide, basic fibroblast growth factor, leptin) Moreover, Fauquier et $a l_{.}^{\left(\mathbf{( s )}^{2}\right.}$ have recently demonstrated that the FS cell network forms an extensive functional intrapituitary circuitry in which information by $\mathrm{Ca} 2+$ and small diffusible molecules, can be transferred via gap junctions over long distances. The finding show that the FS cells are the principal source of annexin I in the anterior pituitary gland and the observations that FS cells are rich in glucocorticoid receptor .

GLUCOCORTICOID hormones and their synthetic analoges have many powerful actions and are widely used for the treatment of inflammation, allergy, and autoimmune diseases. They also exert many effects on central endocrine mechanisms, including powerful inhibitory effects on the hypothalamopituitary-adrenocortical (HPA) axis ${ }^{(\mathbf{9})}$. Regulation of the HPA axis by steroids is not fully understood, but there is substantial evidence that they act in part by controlling the synthesis of regulatory proteins ${ }^{(10)}$. In several model systems glucocorticoids increase the synthesis of lipocortin 1 (LC1; annexin I), a potent antiinflammatory protein ${ }^{(11)}$.

LC1 is a member of the family of annexin

calcium/phospholipid-binding

cytosolic proteins implicated in many cellular $\quad$ processes $^{(\mathbf{1 2 , 1 3})}$.

Glucocorticoids promote de novo synthesis of LC1 in the adenohypophysis and cause the translocation of intracellular LC1 to pericellular sites $^{(\mathbf{1 4 )}}$ as they do in other tissues $^{(15)}$.

Although the mechanism of externalization of LC1, which lacks a signal sequence, is unknown, externalization appears to be essential for mediating many actions of LC1 in the neuroendocrine system ${ }^{\mathbf{( 1 6 )}}$.

We therefore propose that LC1 exported by target cells in response to a glucocorticoid challenge depresses peptide release by binding to cell surface. LC1 receptors on endocrine cells and thereby serves as an autocrine and/or paracrine agent. There is increasing evidence that there are paracrine controls of hormone secretion.

The key role for annexin 1(ANXA1) in mediating the early inhibitory effects of $\mathrm{G}$ Cs on ACTH 
release $^{(\mathbf{1 7})}$. ANXA1 is found in abundance in the anterior pituitary gland in which it is localized to the nonendocrine S100-positive folliculostellate (FS) expression ${ }^{(\mathbf{1 8})}$, phosphorylation status $(19,20)$, and subcellular localization ${ }^{(21)}$ are regulated by GCs. Several lines of evidence have led us to propose that ANXA1 acts as a paracrine/juxtacrine mediator of the inhibitory actions of GC on ACTH release within the anterior pituitary gland ${ }^{(22)}$.

First, GCs cause phosphorylation and exportation of ANXA1 from FS cells at loci adjacent to corticotrophs $^{(23)}$. Second, specific, high-affinity ANXA1 binding sites are expressed on the surface of corticotrophs. Third, in vitro the acute inhibitory effects on the release of ACTH from the corticotrophs. The importance of ANXA1 is mediating the regulatory effects of GCs on ACTH secretion at the pituitary level. The feedback actions of GCs at the pituitary level involve suppression of the gene encoding ACTH, proopiomelanocortin, and more immediate effects that attenuate the release of preformed ACTH from the secretory granules $^{(\mathbf{1 7})}$.

Glucocoticoid (GC) treatment in children or adults suppressed the hypothalamo-pituitary-adrenal axis (HPA). The present study, we tested this hypothesis, using a noninvasive method of steroid administration to explore: (1) prenatal and early neonatal exposure to GC produced long-term changes in adult pituitary corticotrophs. (2) GC affects the expression of annexin-1 (Annxa-1) on the surface of folliculostellate cells. .

\section{MATERIALS \& METHODS}

Animals

Sixty adult male and female albino rats, weighing 200-230 gm were used in this study. They were maintained in 12 hours room light and 12 hours of darkness. They were on normal rat chow and water ad libitum. They were housed for breeding in the animal house, Faculty of Medicine, Cairo University. Groups of two females and one male rat were then housed together overnight. Mating was confirmed the following morning by the presence of vaginal plugs and, at a later stage $(9 \mathrm{~d})$, pregnancy was confirmed by abdominal palpation. Timed pregnant rats were housed five per cage until gestational d 15 when they were isolated in preparation for littering. If litters were found, the day of birth was defined as $\mathrm{d} 0$ for that litter.

\section{Drug administration}

Pregnant and lactating rats were divided into control and treated group(five rats per group). Dexamethasone, as prednisone (Kahira Pharm. and Chem. Industries Company, Cairo), was administered via drinking water $(1 \mathrm{ug} / \mathrm{ml})$ to the rats on d 16-19 of pregnancy or in first week following delivery for lactating rats, Theogaraj et al., $\mathbf{2 0 0 5}{ }^{\mathbf{( 2 4 )}}$. The developing rats were thus exposed to the steroid in utero via the placenta or as neonates via the mother's milk. Control group received normal drinking water throughout pregnancy and lactation. The progeny were left undisturbed until weaning when they were divided according to gender and perinatal treatment and 
caged in groups of four to five until aged $90 \mathrm{~d}$ (young adulthood).

Animals were sacrificed by high dose of ether at $10 \mathrm{am}$ to standardize effects associated with the circadian rhythm. The pituitary gland was excised and processed for Gene expression of Annexin1, histological, immunohistochemical and ultrastructural studies.

Light microscopic examination:

The pituitary gland was fixed in $10 \%$ formol saline solution, processed, embedded in paraffin, sectioned and stained with Haematoxylin and eosin and immunohistochemical stain, Bancroft and Gamble, 2002(25) for ACTH and S100 antibody expression using a primary antibody, which is an epitope specific rabbit antibody (catalog number E2651), purchased from Spring Bioscience Co. Immunostaining required boiling tissue sections in citrate buffer $(\mathrm{pH}$ 6.0) in microwave for 3 minutes, followed by cooling at room temperature before application of the primary antibody for 30 minutes at room temperature. Ultravision detection system, purchased from Lab Vision Corporation (catalog number TP-015-HD) was used to detect the immunoreaction using the streptavidin-biotin-peroxidase technique, followed by counterstaining with Mayer's haematoxylin.

Morphometric study:

The immunostained sections were examined by image analysis using image analyzer computer system “Leica Qwin 500 C” (Cambridge, UK). The optical density and area percent in both ACTH and S100 immunostained sections were measured in all groups at X400 magnification in 10 non- overlapping fields/ section. The surface area of ACTH positive cells was also measured in the same way. The data obtained were statistically analyzed by comparing mean values of different groups by ANOVA test using "SPSS 9" software. Results were considered statistically significant when $P$ value was $<0.05$.

Electron microscopic examination:

The pituitary glands were fixed in $3 \%$ gluteraldehyde, post fixed in $1 \%$ osmium tetroxide, dehydrated and embedded in resin. Semithin sections were cut and stained with toluidine blue. Ultrathin sections were stained by uranyl acetate and lead citrate ,Dawes, 1980 ${ }^{(\mathbf{2 6})}$. Examination was done on the TEM "Zeiss 10S" (Carl Zeiss, Obekochen, Germany), in the Histology Department, Faculty of Medicine, Cairo University.

Detection of annexin-1 by RT-PCR. RNA extraction:

Total RNA was extracted from pineal body tissue samples using the SV total RNA isolation system kit (Promega, Madison, USA) according to the manufacturer's recommendations

\section{RT-PCR:}

cDNA was generated from $5 \mathrm{mg}$ of total RNA extracted with 20pmol oligodt primer and was denaturated at 70C for $2 \mathrm{~min}$ then a transcription mixture containing $50 \mathrm{mmol} \mathrm{kcl}$, dNTPs and 200 unit of MMLV reverse transcriptase was added the reaction was placed at $42 \mathrm{C}$ for 1 hour then $95 \mathrm{C}$ for $5 \mathrm{~min}$ to stop the reaction. Then PCR reaction was performed by adding the PCR mix 
which contained $10 \mathrm{mmol} / \mathrm{L}$ tris HCL PH 8.3, 2.3 unit of taq polymerase, $100 \mathrm{mmol}$ dNTPS and $100 \mathrm{mmol}$ of each specific annexin-1primer with the following sequence, forward: CAGCCTCTTGAGTAGCTGGReverse:

GTCAGGAGTTCGAGACCAGC.

Then the reaction mixture was subjected to 40 cycles of $950 \mathrm{C}$ for $1 \mathrm{~min}, 550 \mathrm{C}$ for $1 \mathrm{~min}$ and $720 \mathrm{C}$ for $2 \mathrm{~min}$. after the last cycle a final extension at $720 \mathrm{C}$ for $10 \mathrm{~min}$ was done,Valerie et al1999 ${ }^{(27)}$.

Agarose gel electrophoresis:

All PCR products were electrophoresed on $2 \%$ agarose stained with ethidium bromide and visualized by UV transilluminator. Fragment sizes were 113 pb.

\section{Gel documentation:}



Fig. (1)
The PCR products were semiquantitated using the gel documentation system (BioDO, Analyser) supplied by Biometra.

\section{RESULTS}

A Light microscopic results:

1) Haematoxylin and Eosin:

The anterior lobe of the pituitary gland of a control rat showed normal appearance of its acidophil, basophil cells and blood sinusoids in between (fig. 1). In the prenatal group the different cells of the gland were also normal (fig. 2). In the neonatal group the basophils were faintly stained and widely spaced) in some areas and of normal appearance of in other areas. The sinusoids were excess in number and markedly dilated (fig. 3).

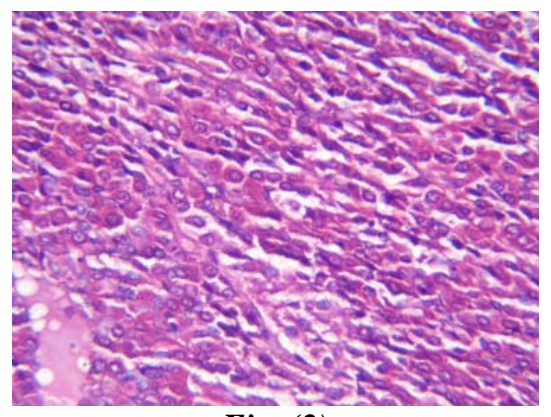

Fig. (2)

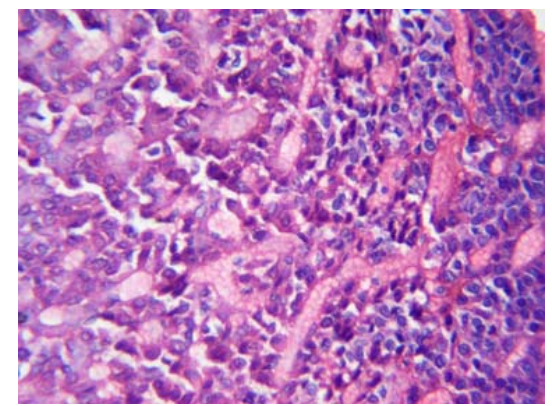

Fig. (3) 
2) Immunohistochemical and morphometric results:

a) ACTH immnunoreaction of corticotrophs

In the control group the corticotrophs showed moderate reaction to ACTH antibody (fig. 4). In

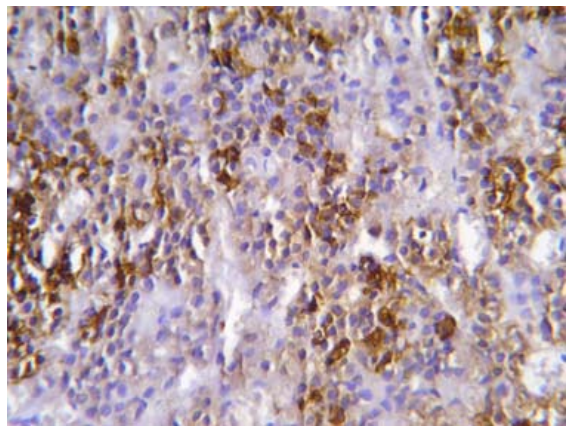

Fig. (4) the prenatal group there was decreased immunoreaction and number of corticotrophs (arrows) (fig. 5). In the neonatal group the immunoreaction number of corticotrophs increased to be near those of the control group (fig. 6).

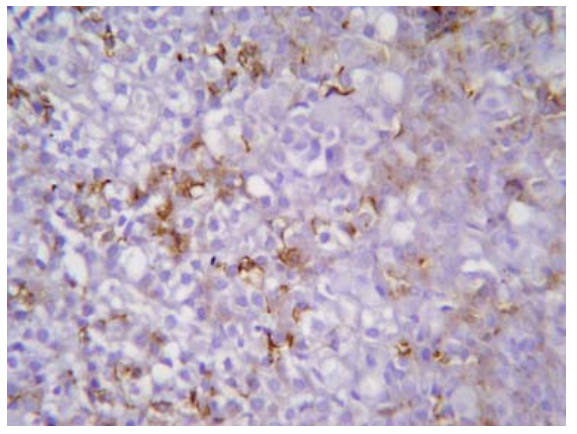

Fig. (5)

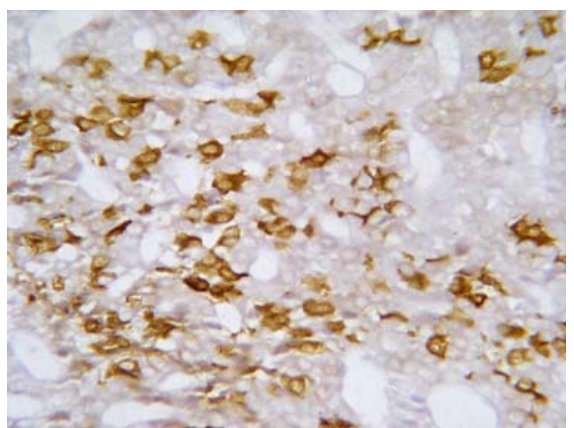

Fig. (6)

b) $\mathrm{S} \mathbf{1 0 0}$ protein immnunoreaction of folliculostellate cells

The folliculostellate cells of control group showed moderate reaction of S 100 protein (fig. 7). In the prenatal group reaction decreased (fig. 8). In the noenatal group there was increased reaction of folliculostellate cells to be near the control group (fig. 9). 


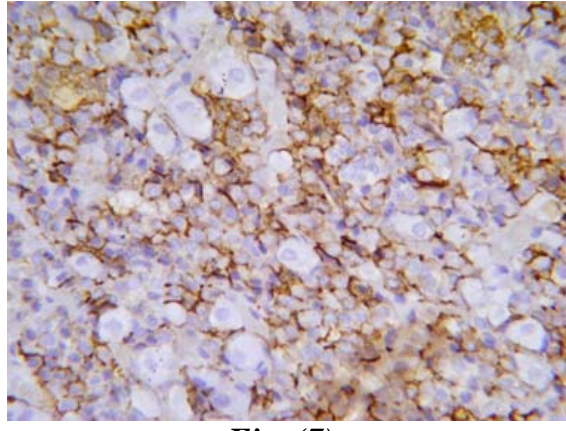

Fig. (7)

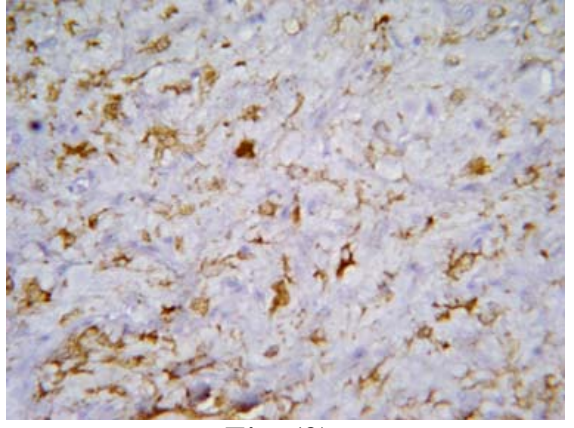

Fig. (8)

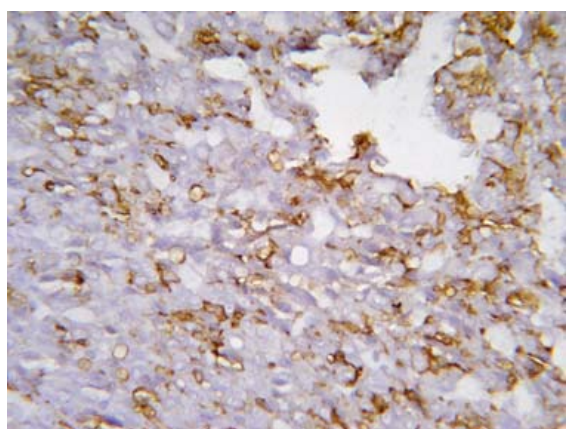

Fig. (9)

The optical density of ACTH antibody was significantly decreased in both prenatal and neonatal groups of dexamethasone administration compared to the control (Table 1 \& fig. 10). The area percent of ACTH was significantly decreased in both groups than the control with marked decrease in the prenatal group (fig. 11). Regarding $S 100$ protein antibody the optical density was significantly decreased in both prenatal and neonatal groups (Table 1 \& fig. 12) while its area percent decreased significantly in prenatal group compared to the control (fig. 13).

Table 1: Mean Optical density of ACTH, Area \% of ACTH, Optical density of S 100 protein and Area \%of $S 100$ protein.

\begin{tabular}{|c|c|c|c|c|c|c|c|c|}
\hline \multicolumn{2}{|c|}{$\begin{array}{llll}\begin{array}{l}\text { Area } \% \text { of } \\
\text { protein }\end{array} & \mathrm{S} & \mathbf{1 0 0} \\
\end{array}$} & \multicolumn{2}{|c|}{$\begin{array}{l}\text { Optical density of } \mathrm{S} \\
100 \text { protein }\end{array}$} & \multicolumn{2}{|c|}{ Area \% of ACTH } & \multicolumn{2}{|c|}{$\begin{array}{l}\text { Optical density of } \\
\text { ACTH }\end{array}$} & \\
\hline$P$ & Mean \pm SD & $P$ & Mean \pm SD & $P$ & Mean \pm SD & $P$ & Mean \pm SD & \\
\hline & $16.526+6.29$ & & $1.026+0.01$ & & $20.318+5.67$ & & $1.194+0.02$ & Control \\
\hline $0.001^{*}$ & $6.056+3.18$ & $0.001 *$ & $0.953+0.02$ & $0.001^{*}$ & $3.599+1.40$ & $0.001 *$ & $0.93+0.03$ & prenatal \\
\hline 0.93 & $15.595+6.84$ & $0.001^{*}$ & $0.959+\mathbf{0 . 0 2}$ & $0.013^{*}$ & $15.162+2.85$ & $0.001 *$ & $0.988+0.04$ & Neonatal \\
\hline
\end{tabular}




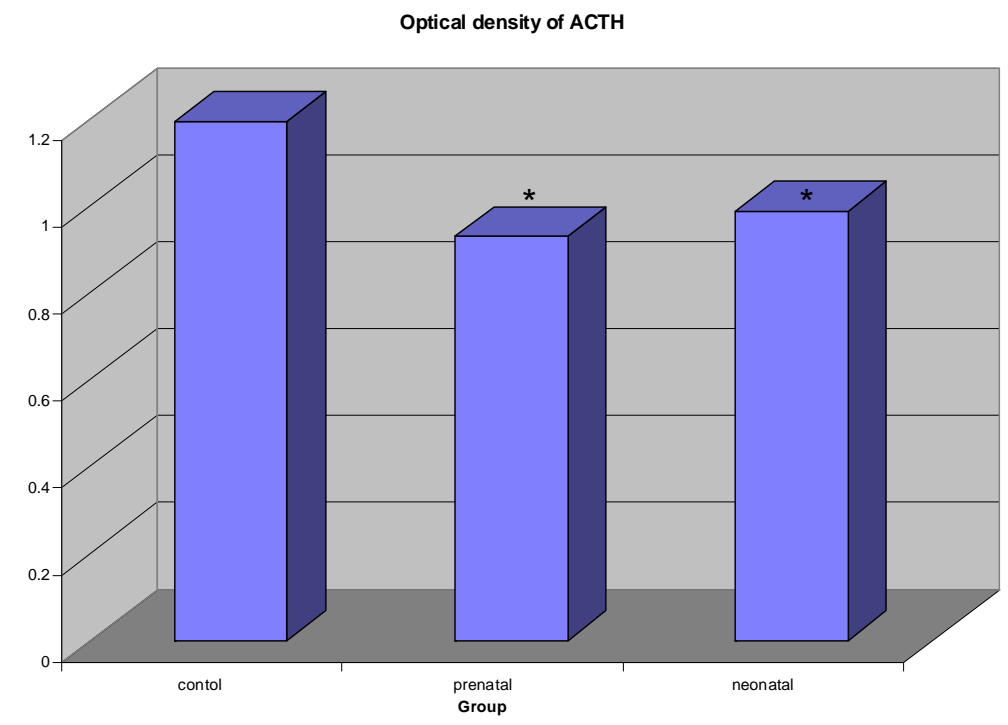

Fig. 10: A histogram of the mean optical density of ACTH antibody in the studied groups.

Area \% of ACTH

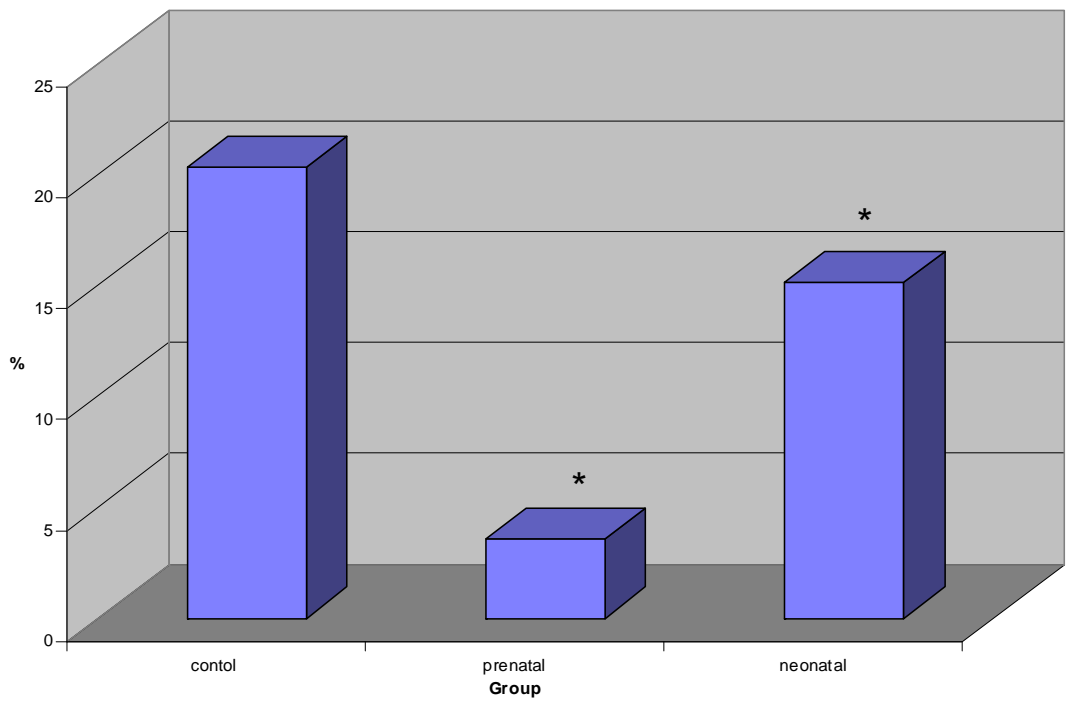

A

Fig. 11: A histogram of the mean area percent of ACTH antibody in the studied groups. 


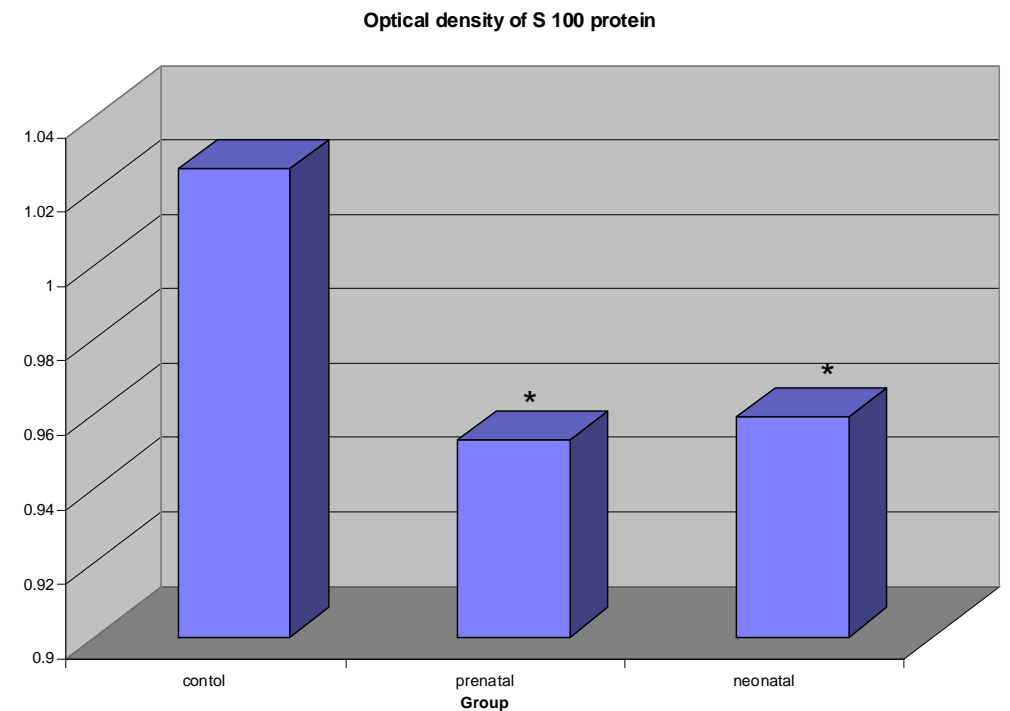

Fig.12: A histogram of the mean optical density of $S 100$ protein antibody in the studied groups.

Area $\%$ of $\mathrm{S} 100$ protein



Fig. 13: A histogram of the mean area percent of $S 100$ protein antibody in the studied groups. 
B Electron microscopic results:

The corticotrophs of control group showed their characteristics of angular processes of their cell membrane and euchromatic nuclei. Medium sized granules are distributed in both the periphery of the cell and near the centre of the cell beside the nucleus, normal Golgi apparatus and mitochondria were alsonoticed (fig. 14). In the prenatal group the

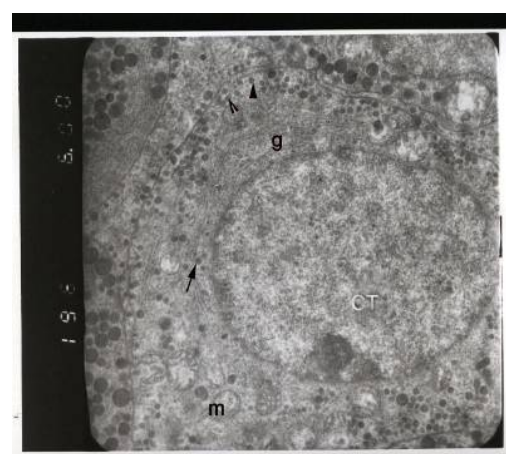

Fig. (14) corticotroph showed very few granules in the periphery and were absent from the centre of the cell. Secondary lysosomes were seen (fig. 15). In the neonatal group the corticotrophs showed normal distribution of its granules in both the periphery and the centre of the cell. The mitochondria were of normal appearance

(fig.

16).

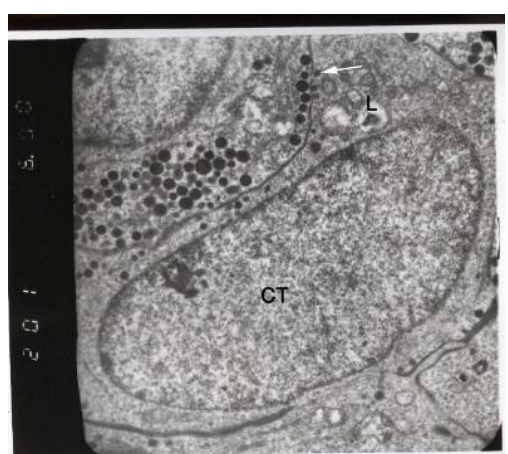

Fig. (15)

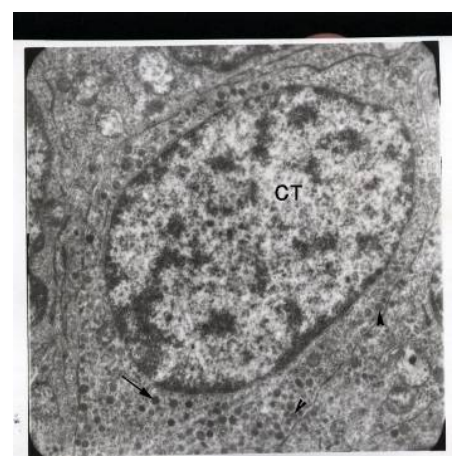

Fig. (16)

ANXA1 expression in the pituitary gland:

The effects of prenatal and neonatal dexamethasone treatment on the expression of ANXA1 in pituitary gland of adult rats, as determined by
Westernblot analysis were show table 2 , figure 4

ANXA1 was detected in the pituitary tissue in control rats $(121.65 \pm 10.9)$ and steroid-treated rats ANXA1expression of the pituitary 
tissue was significantly decreased in prenatal (62.675 $\pm 16.4, \mathrm{p}<0.05)$, and in neonatal group $(77.72 \pm 16.4, \mathrm{p}<0.05)$ so dexamethasone treatment significantly reduced the annexin-1 expression when compared with corresponding values of control group.,but deacreased in the prenatal group more than the neonatal group.

Table (2): Annexin-1 gene expression in control, prenatal and neonatal GC groups:

\begin{tabular}{|l|l|l|}
\hline & Mean \pm SD & P value \\
\hline Control & $121.65+10.9$ & \\
\hline Prenatal & $62.675+16.4$ & $0.001^{*}$ \\
\hline Neonatal & $77.72+16.4$ & $0.001^{*}$ \\
\hline
\end{tabular}

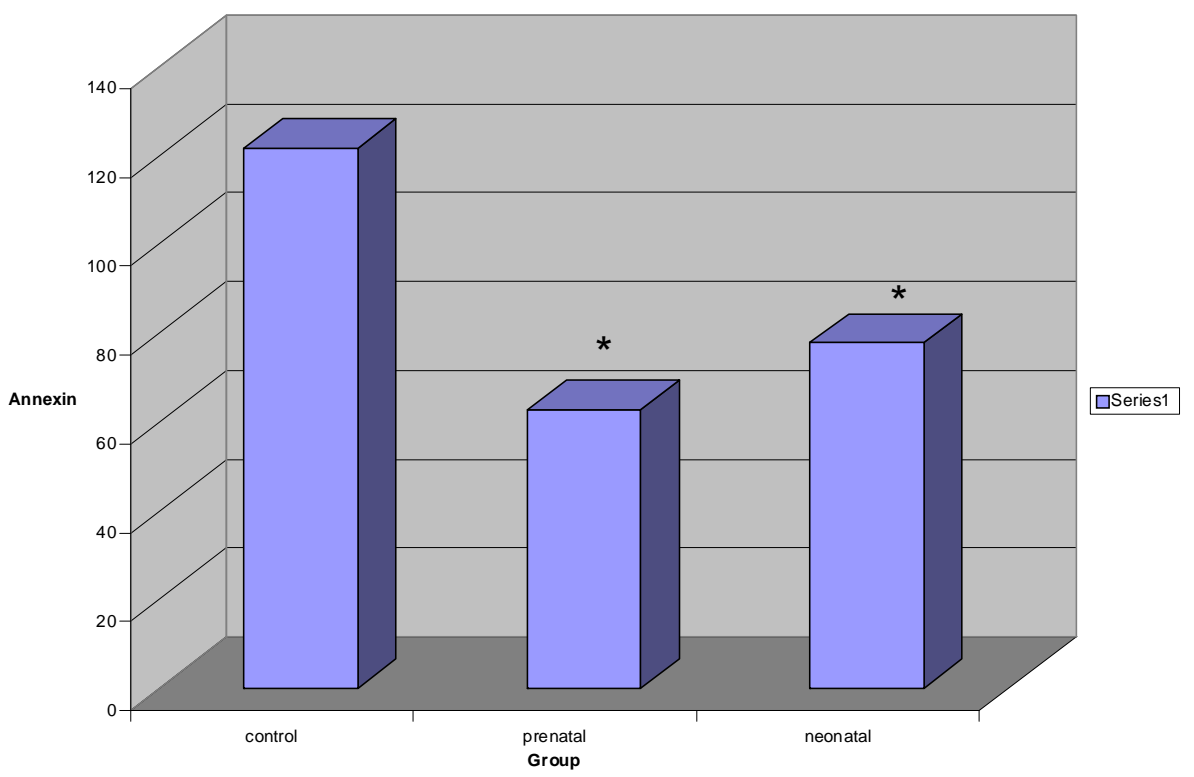

Fig. (17) Annexin -1 gene experission in control, prenatal, and neonatal GC groups $*=$ Statistically significant as compared to control $(P<0.05)$.

\section{DISCUSSION}

In the present work Glucocorticoids treatment in prenatal and neonatal life induced long-term sequelae which were manifested in adult life. It affected the sensitivity of HPA due to feedback of GC on
ACTH secretion and subsequently GC secretion of adrenals ${ }^{(24)}$.

Our results demonstrated that the taking of (GC) in the form dexamethasone showed that the optical density of ACTH antibody, the area percent of ACTH and the optical density of $S 100$ protein 
antibody were significantly decreased in both prenatal and neonatal groups; while its area percent decreased significantly in prenatal group.In the prenatal group only the corticotroph showed very few granules in the periphery and were absent from the centre of the cell. Secondary lysosomes were seen as compered with normal untreated rats. These results are to some extent agreeing with Theogaraj et al $^{(24)}$ studies that showed that prenatal dexamethasone treatment reduced the size but not the number of FS cells. It also caused a marked reduction in corticotroph number and impaired granule margination without affecting other aspects of corticotroph morphology. But less marked effects on pituitary cell morphology and number were evident in tissue of neonatally treated rats.

These results are in aggreement with researrches about the glucocorticoid programming of the brain. Maternal and/or foetal stressors alter developmental changes in specific brain structures with persistent effects ${ }^{(28)}$. Glucocorticoids are important for normal maturation in most regions of the developing $\mathrm{CNS}^{(29)}$, initiating terminal maturation, the remodelling of axons and dendrites, and for cell survival ${ }^{(30)}$. Prenatal glucocorticoid administration retards brain weight at birth in sheep delaying maturation of neurons, myelination, glia andvasculature ${ }^{(31)}$.

Exposure to glucocorticoids in utero has widespread acute effects upon neuronal structure and synapse formation $^{(32)}$, and may permanently alter brain structure (33). In rhesus monkeys, treatment with antenatal dexamethasone caused dose dependent neuronal degeneration of hippocampal neurons and reduced hippocampal volume, effects which persisted at 20 months of age ${ }^{(34)}$. Foetuses receiving multiple lowerdose injections showed more severe damage than those receiving a single large injection.

Given such widespread effects of glucocorticoids, it is unsurprising that GR and MR are highly expressed in the developing brain with complex ontogenies to allow selectivity of effects $^{(35)}$.

Our results revealed that both the prenatal and neonatal adminsteration of (GC) decrease annexin-1gene expression as compared with values of control groups. These results are in agreement with Teogaraj etal results $^{(24)}$ who show that, when administered by a non invasive process, perinatal and neonatal GC treatment exerts profound effects on the adult pituitary gland, impairing the ANXA1-dependent GC regulation of $A C T H$ release and altering the cell profile and morphology.

Lee Chapman et al, $^{(22)}$ have found that annexin $I$ is a paracrine mediator of glucocorticoid action and that the FS cells are an important target for glucocorticoid action. On a temporal basis, the glucocorticoid-induced

translocation of annexin $I$ in the rat pituitary parallels the onset of the steroid inhibition of ACTH release. And annexin I is one of the regulatory proteins produced by FS cells and plays a primary role in the acute inhibitory actions of glucocorticoids 
on ACTH, PRL, GH, and TSH release In freeze-substituted sections of mouse anterior pituitary, immunogold electron microscopy revealed annexin I.

Glucocorticoids influence all types of inflammatory events, no matter what is their cause. They induce the lipocortin-1 (annexin-1) synthesis, which then binds to cell membranes preventing the phospholipase A2 from coming into contact with its substrate arachidonic acid. This leads to diminished eicosanoid production. The cyclooxygenase (both COX-1 and COX-2) expression is also suppressed, potentiating the effect. In other words, the two main products in inflammation Prostaglandins and Leukotrienes are inhibited by the action of Glucocorticoids ${ }^{(36)}$.

Glucocorticoids also stimulate the lipocortin-1 escaping to the extracellular space, where it binds to the leukocyte membrane receptors and inhibits various inflammatory events: epithelial adhesion, emigration, chemotaxis, phagocytosis, respiratory burst and the release of various inflammatory mediators (lysosomal enzymes, cytokines, tissue plasminogen activator, chemokines etc.) from neutrophils, macrophages and mastocytes ${ }^{(36)}$.

In addition to the effects listed above, use of high dose steroids for more than a week begins to produce suppression of the patient's adrenal glands because the exogenous glucocorticoids suppress hypothalamic corticotropin releasing hormone (CRH) and pituitary adrenocorticotropic hormone (ACTH). With prolonged suppression, the adrenal glands atrophy (physically shrink) and can take months to recover full function after discontinuation of the exogenous glucocorticoid $^{(36)}$.

The studies done by John et al. ${ }^{(\mathbf{1 7 )}}$ on GC treatment on pituitary function showed that the feedback actions of GCs at the pituitary level involve suppression of the gene encoding ACTH, proopiomelanocortin, and more immediate effects that attenuate the release of preformed ACTH from the secretory granules .And the annexin 1 (ANXA1) is the mediating factor for the early inhibitory effects of GCs on ACTH release.

The mechanism(s) by which LC1 suppresses pituitary hormone release is not known, although Christian et al. ${ }^{(37)}$ studies strongly favor actions via a cell surface "receptor." Also the study demonstrates for the first time the presence of high affinity LC1binding sites on the surface of multiple anterior pituitary cell types and, thus, adds further support to this view.

\section{REFERENCES}

1. Matthews SG (2000) Antenatal glucocorticoids and programming of the developing CNS. Pediatr Res 47:291-300

2. Crane J, Armson A, Brunner M, De La Ronde S, Farine D, Keenan-Lindsay L, Leduc $L$, Schneider C, Van Aerde J (2003) Antenatal corticosteroid therapy for fetal maturation. J Obstet Gynaecol Can 25:45-52

3. Cole TJ. (1995) Cloning of the mouse 11beta-hydroxysteroid dehydro-genase type 2 gene: 
tissue specific expression and localizationin distal convoluted tubules and collecting ducts of the kidney.Endocrinology, 136 46934696.

4. Speirs H, Seckl J \& Brown R. (2004) Ontogeny of glucocorticoid receptor and 11bhydroxysteroid dehydrogenase type 1 gene expressionidentifies potential critical periods of glucocorticoid susceptibility during development. Journal ofEndocrinology 181:105-116.

5. Brown RW, Diaz R, Robson AC, Kotelevtsev Y, Mullins JJ, Kaufman MH \& Seckl JR (1996) The ontogeny of 11bhydroxysteroiddehydrogenase type 2 and mineralocorticoid receptor programming expression reveal intricate control of glucocorticoid action indevelopment. Endocrinology 1996 137: 794-797.

6. Sun K, Yang K \& Challis JRG (1997) Differential expression of 11betahydroxysteroid

dehydrogenase types 1 and 2 in human placentaand fetal membranes. Journal of Clinical Endocrinology and Metabolism 82: 300-305.

7. Perryman EK (1989) Folliculostellate cells of the pituitary gland. Bioscience 39:81-88

8. Fauquier $T$, Guerineau NC, McKinney RA, Bauer $K$, Mollard P (2001) Folliculostellate cell network: a route for long distance communication in the anterior pituitary. Proc Natl Acad Sci US A 98:8891-8896.

9. Munck A, Guyre PM, Holbrook NJ (1984) Physiological functions of glucocorticoids in stress and their relation to pharmacological actions. Endocr Rev35:25-44

10. Dayanithi G, Antoni FA (1989) Rapid as well as delayed inhibitory effects of glucocorticoid hormones on pituitary adrenocorticotropic hormone release are mediated by type II glucocorticoid receptors and require newly synthesize messenger ribonucleic acid as well as protein. $\mathrm{J}$ Endocrinol 125:308-313

11. Buckingham JC, Flower RJ (1997) Lipocortin 1: a second messenger of glucocorticoid action in the hypothalamopituitary-adrenocortical axis. Mol MedToday 3:296-302

12. Raynal P, Pollard HB (1994) Annexins: the problem of assessing the biological role for a gene family of multifunctional calcium- and phospholipidbinding proteins. Biochim Biophys Acta 1197:63-93

13. Buckingham JC (1996) Stress and the neuroendocrine-immune axis: the pivotal role of glucocorticoids and lipocortin-1. Br J Pharmacol 118:1-19

14. Philip JG, Flower RJ, Buckingham JC (1997) Glucocorticoids modulate the cellular disposition of lipocortin 1 in the rat brain in vivo and in vitro. NeuroReport 8:1871-1876

15. Ambrose MP, Hunninghake GW (1990) Corticosteroids increase lipocortin I in BAL fluid from normal individuals and patients with lung disease. J Appl Physiol 68:1668-1671 
16. Taylor AD, Christian HC, Morris JF, Flower RJ, Buckingham JC (1997) An antisense oligodeoxynucleotide to lipocortin 1 reverses the inhibitory actions of dexamethasone on the release of ACTH from rat pituitary tissue in vitro. Endocrinology 138:29092918

17. John CD, Christian HC, Morris JF, Flower RJ, Solito E, Buckingham JC (2004) Annexin 1 and the regulation of endocrine function. Trends Endocrinol Metab 15:103-109

18. Smith T, Flower RJ, Buckingham JC (1993) Lipocortins 1, 2 and 5 in the central nervous system and pituitary gland of the rat: selective induction by dexamethasone of lipocortin 1 in the anterior pituitary gland. Mol Neuropharmacol 3:45-55

19. John C, Cover P, Solito E, Morris J, Christian H, Flower R, Buckingham J (2002) Annexin 1-dependent actions of glucocorticoids in the anterior pituitary gland: roles of the $\mathrm{N}$ terminal domain and protein kinase C. Endocrinology 143: 3060-3070

20. Solito E, Mulla A, Morris JF, Christian HC, Flower RJ, Buckingham JC (2003) Dexamethasone induces rapid serine-phosphorylation and membrane translocation of annexin 1 in a human folliculostellate cell line via a novel nongenomic mechanism involving the glucocorticoid receptor, protein kinase $\mathrm{C}$, phosphatidylinositol 3-kinase, and mitogen-activated protein kinase. Endocrinology 144:11641174

21. Taylor AD, Cowell AM, Flower J, Buckingham JC (1993) Lipocortin 1 mediates an early inhibitory action of glucocorticoids on the secretion of ACTH by the rat anterior pituitary gland in vitro. Neuroendocrinology 58:430-439

22. Chapman $L$, Nishimura A, Buckingham JC, Morris JF, Christian HC (2002) Externalization of annexin I from a folliculo-stellate-like cell line. Endocrinology 143:4330-4338

23. Tierney T, Christian HC, Morris JF, Solito E, Buckingham JC (2003) Evidence from studies on cocultures of TtT/GF and AtT20 cells that Annexin 1 acts as a paracrine or juxtacrine mediator of the early inhibitory effects of glucocorticoids on ACTH release. J Neuroendocrinol 15:1134-1143

24. Theogaraj, E.; John, C.D.; Christian, H.C.; Morris, J.F.; Smith, S.F. and Buckingham, J.C. (2005) Perinatal glucocorticoid treatment produces molecular, functional and morphological changes in the anterior pituitary gland of the adult male rat. Endocrinology, 146 (1): 4804-4813.

25. Dawes, C.J. (1980) Biological techniques for transmission electron microscopy, 1st edn., Fadd Research Industries Pub. Inc., 1-16.

26. 26-Bancroft, J.D. and Gamble, M. (2002) Theory and Practice of 
Histological Techniques, 5th ed., Churchill Livingstone, London UK, 130,426.

27. Valerie Traverso, Helen C. Christian, John F. Morris, and Julia C. Buckingham (1999) Lipocortin 1 (Annexin 1): A Candidat Paracrine Agent Localized in Pituitary FolliculoStellate

Cells.Endocrinology1404:311-19.

28. Weinstock M2001. Alterations induced by gestational stress in brain morphology and behaviour of the offspring. Progress in Neurobiology 65 427-451.

29. Meaney MJ, Diorio J, Francis D, Widdowson J, LaPlante $P$, Caldji C, Sharma S, Seckl JR \& Plotsky PM (1996) Early environmental regulation of forebrain glucocorticoid receptor gene expression: implications for adrenocortical responses to stress. Developmental Neuroscience 18 49-72.

30. Meyer JS (1983) Early adrenalectomy stimulates subsequent growth and development of the rat brain. Experimental Neurology 82 432446.

31. Huang WL, Harper CG, Evans SF, Newnham JP \& Dunlop SA (2001) Repeated prenatal corticosteroid administration delays astrocyte and capillary tight junction maturation in fetal sheep. International Journal of Developmental Neuroscience 19: 487-493.

32. Antonow-Schlorke I, Schwab M, Li C \& Nathanielsz PW (2003) Glucocorticoid exposure at the dose used clinically alters cytoskeletal proteins and presynaptic terminals in the fetal baboon brain.Journal of Physiology 547: 117-123.

33. Matthews SG (2000) Antenatal glucocorticoids and programming of the developing CNS. Pediatric Research 47: 291-300.

34. Uno H, Lohmiller L, Thieme C, Kemnitz JW, Engle MJ, Roecker EB \& Farrell PM (1990) Brain damage induced by prenatal exposure to dexamethasone in fetal rhesus macaques. I. Hippocampus. Developmental Brain Research 53: 157-167.

35. Fuxe K, Wikstrom A-C, Okret S, Agnati LF, Harfstrand A, Yu Z-Y, Granholm L, Zoli M, Vale W \& Gustafsson J-A (1985) Mapping of glucocorticoid receptor immunoreactive neurons in the rat tel- and diencephalon using a monoclonal antibody against rat liver glucocorticoid receptor. Endocrinology 117: 1803-1812.

36. Munck A, Guyre PM, Holbrook NJ (1984) Physiological functions of glucocorticoids in stress and their relation to pharmacological actions. Endocr Rev 35:25-44

37. Christian H. C., Taylor A. D., Flower R. J., Morris R. J. and Buckingham (1997) Characterization and Localization of Lipocortin 1-Binding Sites on Rat Anterior Pituitary Cells by Fluorescence-Activated Cell Analysis/Sorting and Electron Microscopy. Endocrinology138, No. 12 5341-5351 


\section{التأثير الممتد لاعطاء مادة الكورتيزون على خلايا الغدة النخامية فى الاجنة وحديثى الولادة من الفئران}

د.طارق الغمراوى، د.ليلى أحدد السيد - قسم الثتريح وقسم علم وظائف الاعضاء

المقدمة :بلعب الكورتيزول دورا هاما فى تتظيم خلايا الغدة النخامية من الناحية التشريحية والوظيفية والتى تتأثز بشكل ملحوظ عند اعطائه عن طريق الفم للاجنة او حديثى الولادة

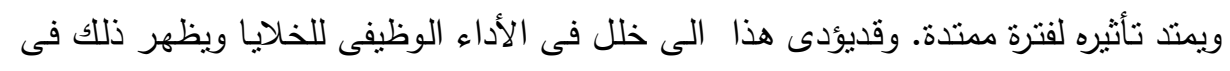

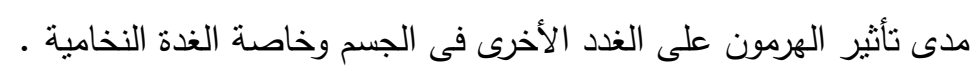

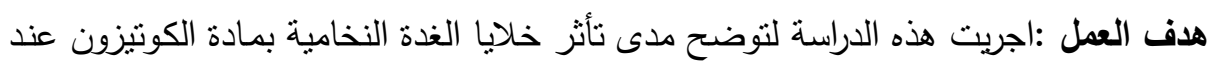

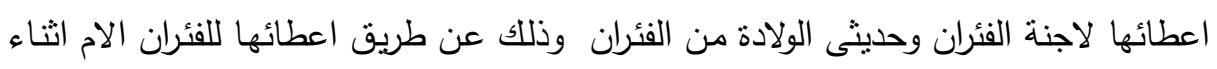

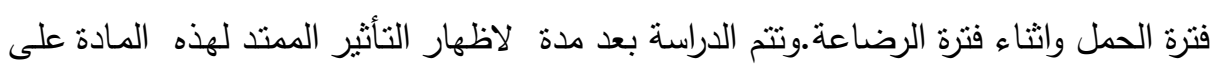
الخلايا المـادة والطرق :استخدم فى هذه الدراسة ستون من الفئران الذكور والإناث وتم وضع واحد

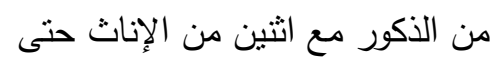

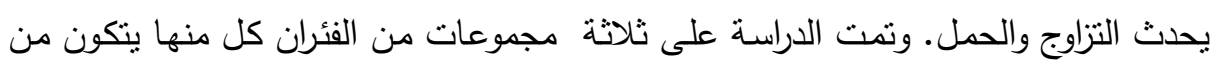





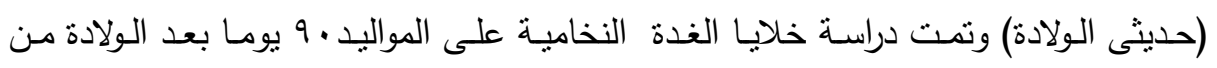
الناحية التركيبية وكذلك قياس جين مادة الانكسين - الني خلاياالغدة النخامية. النتائج: قد أظهرت الدراسة وجود نقص فى كمية هورمون ايه سى تى اتش المنظم لافراز الكورتيزون من الغدة الكظريـة وكذلك مادة الاس . ․



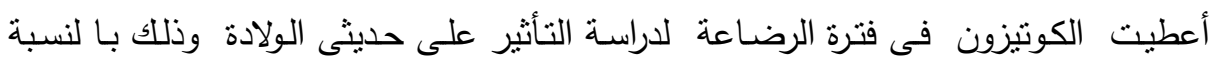

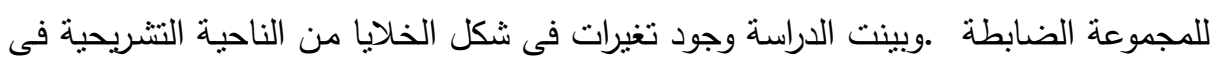

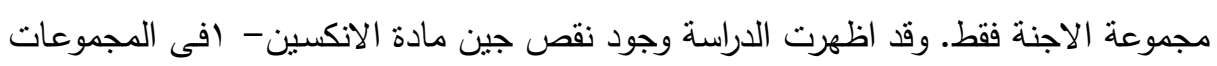


التى اعطيت الكونيزون كأجنة وفى اثناء فترة الرضاعة وذللك بالمقارنة بالمجموعة الضابطة الاستتتاج: يمكن استتناج التأثير النتريحى والوظيفى للكورتيزون على خلى خلاهيا الغدة النخامية

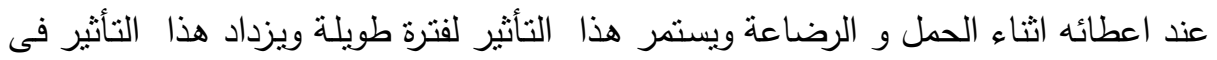
مجموعة الاجنة اكثر من اعطائه لحديثى الولادة ذلك بمقارنتها بالتاثير الطبيعى دون تاثير لئهر

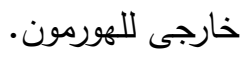

